\title{
A new approach to studying worship
}

\begin{abstract}
Book Title:
Worship in the network culture: Liturgical ritual studies. Fields and methods, concepts and metaphors
\end{abstract}

\section{Book Cover:}

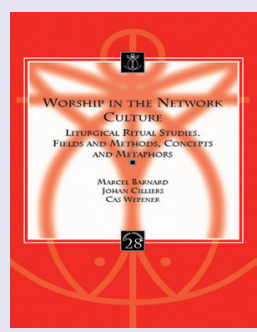

Authors:

Marcel Barnard

Johan Cilliers

Cas Wepener

ISBN:

978-90-429-3069-8

Publisher:

Leuven (Peeters), 2014, €64*

*Book price at time of review

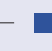

Review Title:

A new approach to studying worship

Reviewer:

Hennie J.C. Pieterse ${ }^{1}$

\section{Affiliation:}

${ }^{1}$ Department of Practical Theology, University of South Africa, South Africa

\section{Email:}

pietehjc@absamail.co.za

\section{Postal address:}

262 Marais Street, Brooklyn, Pretoria 0181, South Africa

\section{Read online:}

Firstly, I give my personal experience regarding the changing liturgical scene in our country. After the political change to a full democracy with a new constitution in South Africa in 1994, Prof Cas Vos and I decided to write a book on worship in the new situation of change on all fronts - Hoe lieflik is U woning, published in 1997. One of the chapters I wrote was Chapter 4 in which I expressed my anticipation concerning the direction that future study in worship will take. I addressed the need for symbols in a situation where little attention is given to it in the Dutch Reformed Church (DRC) (pp. 122-126), a new focus on ritual (pp. 120-122) and a focus on embodiment in liturgy (pp. 126-130). I wrote on the role of ritual in the new liminal situation in our country, quoting Turner (pp. 131-133), and how a new vision of worship could help in the uniting process of the Dutch Reformed Church family. These ideas were all a surmising and guessing game - I had no idea at that time how it would work and how to study it.

Now there is a fascinating new book in liturgical ritual studies - the solidly based result of 10 years of co-operative research by the three authors. It is a book which has delved into a new approach to liturgical research with anthropological, theological and theoretical as well as practically based perspectives, including exiting reports of liturgical ritual in the South-African and European contexts. The authors argue convincingly for a whole new direction in liturgical ritual research and practice for our times.

The choice of liminality as the golden thread running through the book was a good one, and I appreciate it as a sensitising concept with a heuristic function of perspective and interpretation. In a network society in the late-modern culture of constant flow, but also rootedness, the reader is invited into a fascinating world of liturgical ritual in all its plurality of appearances in this new society. There is no centre concerning what is right and what is wrong anymore. Any form of liturgical ritual in the Christian sense of the word, in different cultures and contexts, is described, accepted and celebrated in this book. It is a liberating experience, also for me personally. I grew up with the classical style of Reformed worship, and in my 15 years of full-time ministry before going to teach at university, I practiced it in this way. It was not a pleasant experience for me to see, in the DRC, pulpits and organs go, to see new American-type songs introduced and to see some classic parts of the worship service dropped. After reading this book, I am liberated from this unpleasant feeling. I can open my arms and accept all forms of liturgical ritual which make sense to worshippers in their culture, context and experience of the network society.

This book works with a fresh new name to describe worship in our contemporary culture, namely liturgical ritual studies. The authors embarked on liturgical ritual study:

... on the modern-day flow, connecting to the networks of what Philip Jenkins has called The next Christendom: The coming of global Christianity. As a consequence, it has at the same time developed local, regional and categorical liturgical identities of reformed, Lutheran and Anglican, black and white, Xhosa, Venda, Zulu, Afrikaans etc., gay and straight Christians. That has extensive consequences for the way that we look at liturgy in our churches. The twenty-first century is all about connecting, and at the same time being rooted ... Some of the descriptions of liturgical ritual in Chapter 1 ... we can place ... somewhere on the axis between rootedness and connectedness. (p. 89)

I repeat: There is no centre anymore. All over the different contexts which this book has studied, people live and function liturgically in the liminality of the flow of the late-modern information society. In this process, elements of Christian symbolism are disconnected from their original environment and are again loaded with new meanings elsewhere in new contexts.

Language which communicates well, especially theological and liturgical language in late-modern societies, is metaphoric language (see for instance Wiersinga [2000]). Therefore, it is fascinating to

How to cite this book review: Pieterse, H.J.C., 2015, 'A new approach to studying worship', Verbum et Ecclesia 36(1), Art. \#1410, 2 pages. http://dx.doi.org/10.4102/ve.v36i1.1410

Copyright: @ 2015. The Authors. Licensee: AOSIS OpenJournals. This work is licensed under the Creative Commons Attribution License. 
see the academic interplay of metaphors and concepts in this academic book in the space of constant liminality. Concepts fixed and set in concrete is no more feasible in academic language, especially not in liturgical ritual studies.

As a contemporary practical theologian, I am happy to see the good practical-theological methodology on studying liminality with an anthropological perspective and a theological perspective in interaction. The anthropological perspective is helpful in empirical mapping, exploring and investigating liturgical ritual in different contexts and cultures. The theological review is helpful in theorising on sacrament and word as well as worship and prayer. This research approach enabled the authors to develop a theology of liminality, however provisionally:

... behind the liminal nature of Christian life and of the Hebrew and Greek Bible a God lights up who is himself liminal in nature. A God who is always on the move, because he is a connected God, communicating with his world and people. His word can never be fixed in eternal truths, his Spirit blows over the earth. But this God is not only connected, he is also rooted: he chose for himself a foothold on earth, on a specific place, Jerusalem or Israel. He 'made himself nothing' (Philippians 2:7) in one man of the Jewish people, Jesus, son of Mary and God incarnate who ascended into heaven. The Holy Spirit emanates from God the
Father and the rooted Son, according to the gospel (John 15:26; 16:14f.) and the Western Christian creeds. In short, God too is rooted as well as connected. (pp. 93-94)

What a beautiful piece of theological writing in the sphere of the field of research in this book!

The authors are open to and inclusive of all forms of worship in each particular context. However, the book does not give much attention to the inherited liturgy of Reformed worship which is still practiced in South Africa in the Gereformeerde Churches, the Ned. Herv. Church and some DRC congregations, especially in the rural areas. The authors have chosen another stream in liturgical rituals for their research, which can explain this.

All of us are grateful for the work the authors have done and for the new direction in liturgical ritual studies. It is a must read for pastors in congregations, for theological students and for lecturers. This book will be a prescribed book for some decades to come.

\section{Reference}

Wiersinga, H., 2000, Op ooghoogte: Portret van een postmodern geloof, Zoetermeer, Meinema. 